Chapter 4

\title{
Soil Erosion After Wildfires in Portugal: What Happens When Heavy Rainfall Events Occur?
}

\author{
L. Lourenço, A. N. Nunes, A. Bento-Gonçalves and \\ A. Vieira
}

Additional information is available at the end of the chapter

http://dx.doi.org/10.5772/50447

\section{Introduction}

In Portugal, as well as in other Mediterranean countries, wildfires and burnt areas have increased significantly since 1970 . This rising trend, although encompassing some periods of lower burnt areas, distinguishes Portugal from other southern European States with the highest number of ignitions and the greatest proportion of burnt areas, particularly in the central and northern regions (Nunes, 2012). Forest fires therefore constitute one of the most significant environmental problems (Moreno, 1989; Vallejo, 1997) and are frequently considered the major cause of soil degradation and desertification (Rubio, 1987).

Wildfires can considerably change hydrological processes and the landscape's vulnerability to major flooding and erosion events (Shakesby and Doerr, 2006; Stoof et al., 2012). Post-fire mudflows and flash floods represent a particularly acute problem in mountainous regions (Tryhorn et al., 2007). In fact, vegetation cover is an important factor in determining runoff and erosion risk (Nunes, 2011). Its removal by fire increases the raindrop impact on the bare soil and reduces the storage of rainfall in the canopy, thus increasing the amount of effective rainfall. Burned catchments are therefore at increased hydrological risk and respond faster to rainfall than unburned catchments (Meyer et al. 1995; Cannon et al. 1998; Wilson, 1999; Stoof et al., 2012). Wildfires also affect the hydrogeological response of catchments by altering certain physical and chemical characteristics of the soils, including their water repellent conditions (Conedera et al. 1998; DeBano et al. 1998; Letey 2001; Martin and Moody 2001; Shakesby and Doerr 2006). Increased runoff can lower the intensity threshold and the amount of precipitation needed to cause a flood event and also exacerbate the impact of precipitation. Combined with steep slopes, this can create the potential for flash floods. 
Various studies in different parts of the world, including Portugal, have shown strong and sometimes extreme responses in runoff generation and soil loss following fires, especially during the earlier stages of the so-called "window-of-disturbance" (Shakesby, 2011).

In general, the first 4-6 months after a fire is often the period of greatest vulnerability to erosion because of the maximum fire potential in summer (July-August) and the likelihood of intense post-wildfire rainfall the following autumn-winter (November-January) (Sala et al., 1994; Andreu et al., 2001). However, soil erosion may reach its peak during the first year after a wildfire and subsequently decline, or in some situations be delayed until later, (much later in some cases) during the window of disturbance, in the third or even the fifth year after a fire (Mayor et al., 2007; Llovet et al., 2009). As noted by Ferreira et al. (2009), since the greatest effects of fire on hydrology and erosion generally occur shortly after a fire, data analysis and discussion is limited to the short-term $( \pm 1$ yr) effects.

Post wildfire hydrological and erosional responses have been assessed at plot and hill slope level in various parts of the world, especially in the Mediterranean region, under natural rainfall conditions (Lourenço, 1989; Sala et al., 1994; Ferreira et al., 1997; Andreu et al., 2001, Coelho et al., 2004; Shakesby and Doerr, 2006).

The hydrogeomorphic responses to wildfire at catchment level have received much less attention than those on smaller scales in locations worldwide, mainly because of the greater practical difficulties and expense involved in monitoring on this scale, and the large chance factor involved in the wildfire burning even a small catchment completely (Shakesby and Doerr, 2006; Shakesby et al., 2006; Shakesby, 2011).

Despite the high rate of occurrences of fires in the European Mediterranean area (Moreira et al., 2001; Pausas, 2004), catchment-scale wildfire studies have mostly been carried out in the USA (Moody et, 2008; Moody and Martin, 2001; Gottfried et al., 2003; Meixner and Wohlgemuth, 2003; Nasseri, 1989; Seibert et al., 2010), South Africa (Scott and Van Wyk, 1990; Scott, 1993, 1997) and Australia (Brown, 1972; Langford, 1976; Prosser and Williams, 1998), and in only a few locations in the European Mediterranean area (Lavabre et al., 1993; Mayor et al., 2007; Ferreira et al, 2008; Stoof et al., 2012). In addition, post-fire monitoring is generally comparatively brief (usually $2-3$ years) due to logistical and financial constraints, meaning that infrequent severe storms may be missed and the full recovery to pre-fire conditions may not be monitored.

Therefore, the impact of burned areas on peak flow and sediment transport in large river catchments has not been fully studied, although it is of the utmost importance to understand the off-site impacts of forest fires (Ferreira et al., 2008). A better understanding of the hydrogeomorphic impacts of fire at catchment level can improve our ability to understand, and therefore possibly predict, the risk of flooding and erosion in burned areas. In fact, when a precipitation event follows a large, high-severity fire, the impacts can cause various kinds of damage on- and off-site including high sediment inputs, downstream flooding, destruction of the aquatic habitat, and damage to human infrastructures.

Moreover, in the Mediterranean region precipitation patterns are highly variable in terms of time, space, amount and duration of events (Durão et al., 2010). The occurrence of heavy, 
often localised, precipitation can cause severe post-fire erosion and increase the risk of flash flooding and debris flow.

The main objective of this work was to evaluate the impact of fire at catchment level, with particular reference to the implications of the off-site hydrological response and erosional processes after severe rainstorms (involving one occurrence in June 2006 and another in July 2006). In fact, the growing probability of catastrophic wildfires in Portugal and elsewhere in the world has increased the need to understand the flood risk and the erosion and depositional responses of burned watersheds.

\section{Study area}

Two catchments (the Pomares and Piodão basins), both located in the mountains of central Portugal, were studied (Figure 1). The study area has a high annual precipitation rate, with an average of $1600 / 1700 \mathrm{~mm} \mathrm{yr}^{-1}$. The rainfall is generally concentrated during the period from October to May, whereas July and August are dry months. According to the Köppen climate classification, it has a Mediterranean Csb type climate.

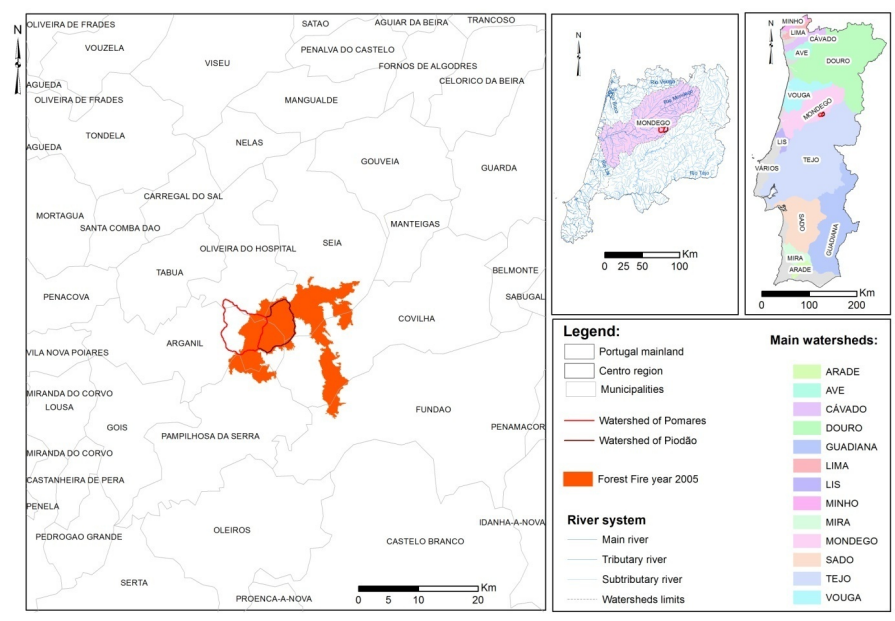

Figure 1. Location of the study basins and the areas affected by forest fire of 2005.

Both catchments lie on Precambrian schist and have shallow, stony, umbric leptosol soils. Both rivers are tributaries of River Alva and, according to the Strahler classification, are fiveorder streams. Some of the characteristics of both basins are presented in Table I. The Piodão and Pomares basins have areas of 34.3 and $44.7 \mathrm{~km}^{2}$ respectively and both have a high elevation gradient of over 1,000 metres. In general, both are surrounded by steep slopes with a top convexity and no basal concavity. More than $90 \%$ of the basin areas have slopes of over 
$20 \%$ and in the Piodão river more than a half of the watershed has slopes of over $50 \%$. A comparative analysis shows the basin ruggedness and coefficient of torrentiality to be slightly higher in the Pomares basin.

\begin{tabular}{ccc}
\hline & Piodão river & Pomares river \\
\hline Basin area $(\mathrm{km} 2)$ & 34.3 & 44.7 \\
\hline Basin gradient $(\mathrm{m})$ & $1047(295-1342)$ & $1069(211-1280)$ \\
\hline Basin ruggedness ${ }^{1}$ & 1.13 & 1.84 \\
\hline Drainage density $\left(\mathrm{km} / \mathrm{km}^{2}\right)$ & 4.13 & 4.42 \\
\hline Coefficient of torrentiality & 29.48 & 41.39 \\
\hline Basin area with slopes greater than 20 percent & 43.9 & 54.7 \\
\hline Basin area with slopes greater than 50 percent & 52.4 & 60 \\
\hline
\end{tabular}

1. maximum change in elevation within a basin, divided by the square root of the basin area (Melton, 1965);

2. the total length of all channels within a basin, divided by the basin area, (Horton, 1945)

Table 1. Main characteristics of both basins.

Important demographic and socio-economic changes have affected the mountain areas of Portugal for at least the last five to six decades. The population of the mountain areas decreased substantially during the second half of the $20^{\text {th }}$ century, leading to the abandonment of agricultural land and a reduction in the size of herds and the amount of forest fuels consumed by grazing and the collection of firewood (Rego, 1992; Moreira et al., 2011; Lourenço, 1996, Nunes, 2012).

Consequently, the landscape has been drastically modified due to the sequential abandonment of traditional land use throughout the second half of the 20th century. The increase in uncultivated land has led to a secondary vegetation succession and modification of the vegetation structure, favouring horizontal and vertical fuel continuity and a consequent increase in flammable biomass. The unmanaged accumulation of large quantities of fuel and the exclusion of fires from forest management has led to a dramatic increase in the magnitude and frequency of forest fires (Carvalho et al., 2002; Moreira et al., 2011).

In addition, afforestation has focused primarily on highly inflammable species, mainly pines (predominantly Pinus pinaster) which also favours the proliferation of forest fires (Shakesby et al., 1996). Once fires break out under these highly dangerous conditions, they spread more easily and cannot be stopped. The low population density, delays in detecting fires, and difficulties in gaining access to the sites where fires tend to start, due to the rugged topography, are other factors that explain the large burnt areas in the central mountain area of Portugal.

The Mediterranean characteristics of the Portuguese climate (warm, dry summers and relatively wet winters) make it prone to wildfires and post-fire soil erosion. In Portugal, the ma- 
jor fires occur in summer, essentially in July and August. At this time of year, several factors combine to create the right conditions for the onset and propagation of wildfires. It is the driest time of year as well as the season for tourism, which includes camping and picnicking, and it is also the time when agricultural refuse and slash are traditionally cleaned and burned after crops have been harvested.

Consequently, as in other Mediterranean countries, Portugal's burnt area has increased significantly in recent decades. In the past three decades, the number of forest fires exceeded half a million ignitions and the total burnt area was approximately $3,236,890$ ha, representing more than a third of the surface area of mainland Portugal (Nunes, 2012). Within the last 30 years (1981-2010), 2003 and 2005 were the worst fire seasons in Portugal, resulting in the burning of almost 430,000 hectares and 325.000 hectares respectively of forest land, shrub land and crops.

The Pomares and Piodão catchments have been severely affected by wildfires since the 1970s. Two large wildfires have affected the greater part of the area of both catchments: the first, between $13^{\text {th }}$ and $20^{\text {th }}$ September 1987, burnt a total of 10,900 hectares, and the second, occurring eighteen years later between $19^{\text {th }}$ and $24^{\text {th }}$ July 2005, affected an area of 17,450 hectares (Lourenço, 2006a b, 2007). Figure 1 shows the burnt area associated with both wildfires.

\section{Methodology}

The post-wildfire hydrological and erosional responses are based on intensive post-event fieldwork to determine the geomorphological impacts and socio-economic implications by collating, collecting and analysing data from field studies that was essential to understanding the meteorology, hydrology and hydraulics of the event.

The meteorological characteristics of the storms that affected the basins were determined using data from a rain gauge installed in the Piodão basin. Daily and 30-minute rainfall intensity measures $\left(\mathrm{I}_{30}\right)$ were chosen for each event, since rainfall frequency studies (Hershfield, 1961; Miller et al., 1973) indicate that in mountainous terrain $79 \%$ of the hourly rainfall occurs within 30 minutes and this type of storm has a short duration, lasting between 10 and 60 minutes (Moody and Martin, 2001).

The fieldwork took place a few days after the events occurred and was based on identifying certain variables:

Indicators of the peak discharge values, mainly cross-section surveys based on flood marks, in addition to signs of flow velocity (witness observations and water super-elevations in river bends or in front of obstacles). High water marks on channel banks, mostly indicated by the deposition of vegetation fragments and silt, were visible in the sites. These marks are very important and provide approximate estimates for reconstructing peak discharges for ungauged cross-sections of rivers affected by floods.

Sediment transfer processes (erosion and deposition on slopes and in river beds, hyperconcentrated mud or debris flow), which may give an indication of local runoff generation processes and flow energy and velocity. 
The post-wildfire hydrological and erosional research benefited from the cooperation of local authorities and organisations that knew the area and had information about the catchment and the event. They provided useful information on the rainfall runoff processes (observation of surface runoff, origin of the runoff) and the local flow characteristics (type of flow - i.e. flood water, hyperconcentrated or debris flow, the presence of woody debris in the flow, approximate surface water flow velocities, blockages formed during the flood and their possible breakup, time and the effect of the collapse of bridges or dykes). The local authorities also provided important information on previous floods, which was relevant in assessing the return period of the flood.

After compiling the information using a Geographical Information System (GIS), detailed information was produced (mainly in the form of maps) which identified the areas heavily affected by water erosion (splash, rill and gully erosion) and sedimentation, as well as the areas affected by flash floods.

\section{Results}

\subsection{The event of $16^{\text {th }}$ June 2006}

A rain gauge installed in the Piodão basin registered high levels of precipitation roughly one year after the July 2005 wildfire for two main events on $16^{\text {th }}$ June and $14^{\text {th }}$ July 2006 . Figure 2 shows the 24 hour precipitation registered by the rain gauge during the month of June, totalling 58mm, distributed over 5 days (Figure 2).

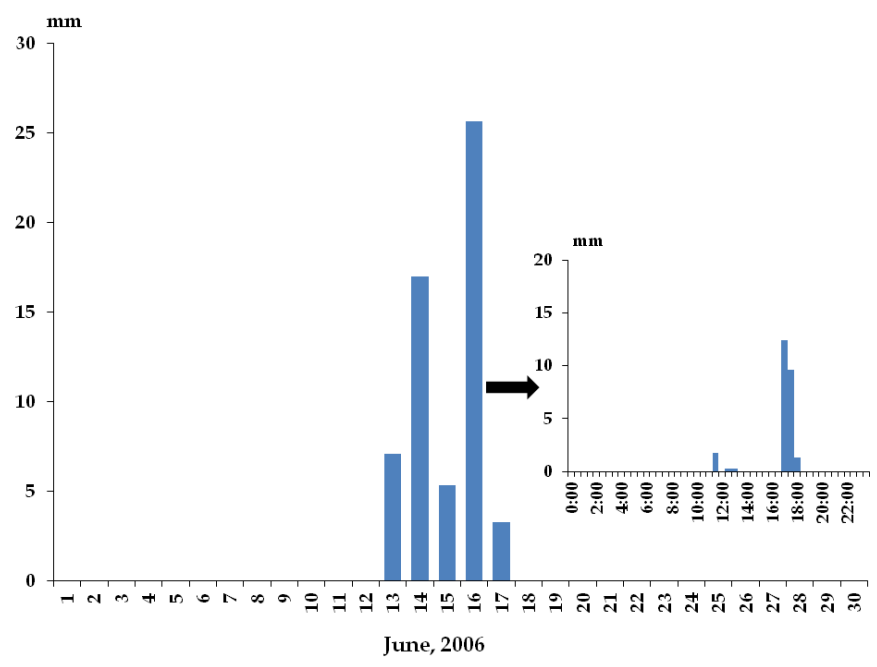

Figure 2. Daily distribution of rainfall in June and bi-hourly distribution on $16^{\text {th }}$ June. 
However, around $50 \%$ of the total rainfall was concentrated on $16^{\text {th }}$ June. A more detailed analysis of the hourly distribution of rainfall on that day shows that $22 \mathrm{~mm}$ were recorded between $5 \mathrm{pm}$ and $6 \mathrm{pm}$.

This event was caused by a high altitude cyclone in the southwest of the Iberian Peninsula which affected the weather in the Portuguese mainland during this period. In mid-latitudes, a 'cyclone' refers to the low pressure centres formed by baroclinic instability, with a typical scale in the order of $1000 \mathrm{~km}$. However, cyclones or cyclonic centres also include any kind of surface depression, even small, weak, shallow low centres of orographic or thermal origin.

Following the high concentration of precipitation recorded on $16^{\text {th }}$ June, several areas in both basins were affected by flash floods, soil erosion and sedimentation processes. Figure 3 summarises the areas worst affected by these processes.

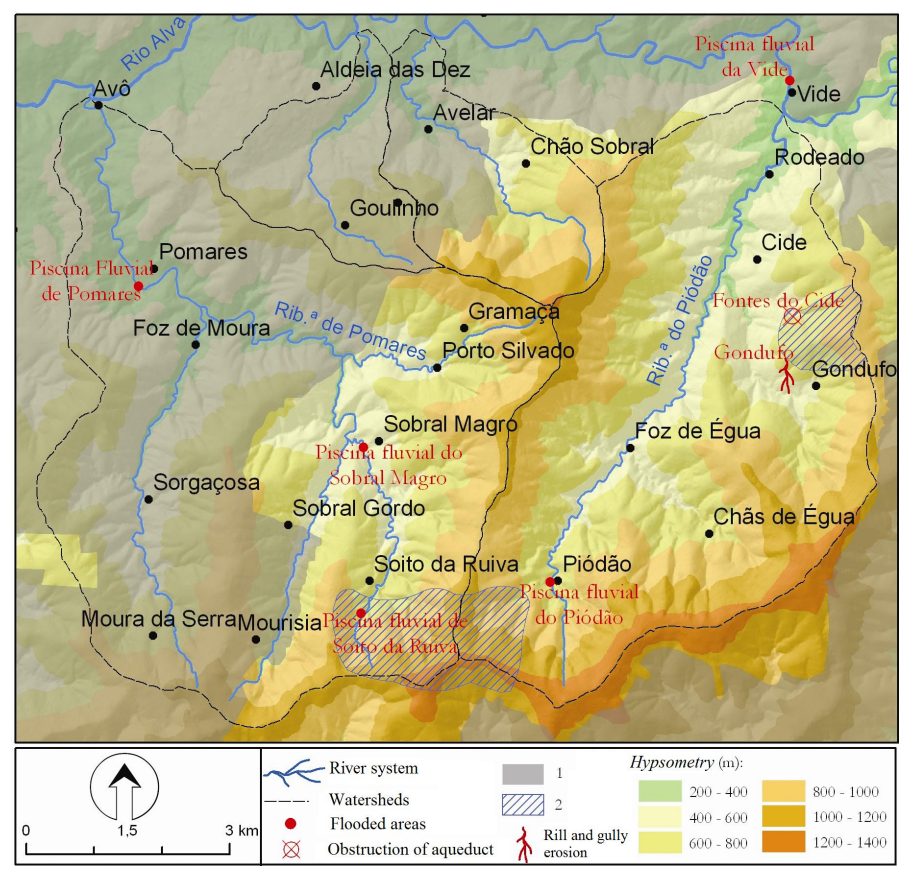

Figure 3. Effects of the intense rainfall after the wildfires.1. Area of the basin not affected by the wildfire of $2005 ; 2$. Areas worst affected by the intense rainfall; Piscina fluvial="river beaches".

The figures 4 and 5 confirm the super-elevation of the flow at the Pomares Bridge (in the Pomares river basin) as well as the flooding of the right bank of the river. In fact, the stream flow created a 2.5 meter waterfront, although the floodgates were open. The impossibility of draining off the volume of water that had accumulated during the intense rainfall, as well as the power of the runoff and stream flow to transport materials obstructed the flow of the water and enlarged the flood area. Figure 5 simulates the peak discharge level and shows 
the tonnes of material, mainly branches of trees and shrubs, carried downstream, which created a blockage at the bridge.

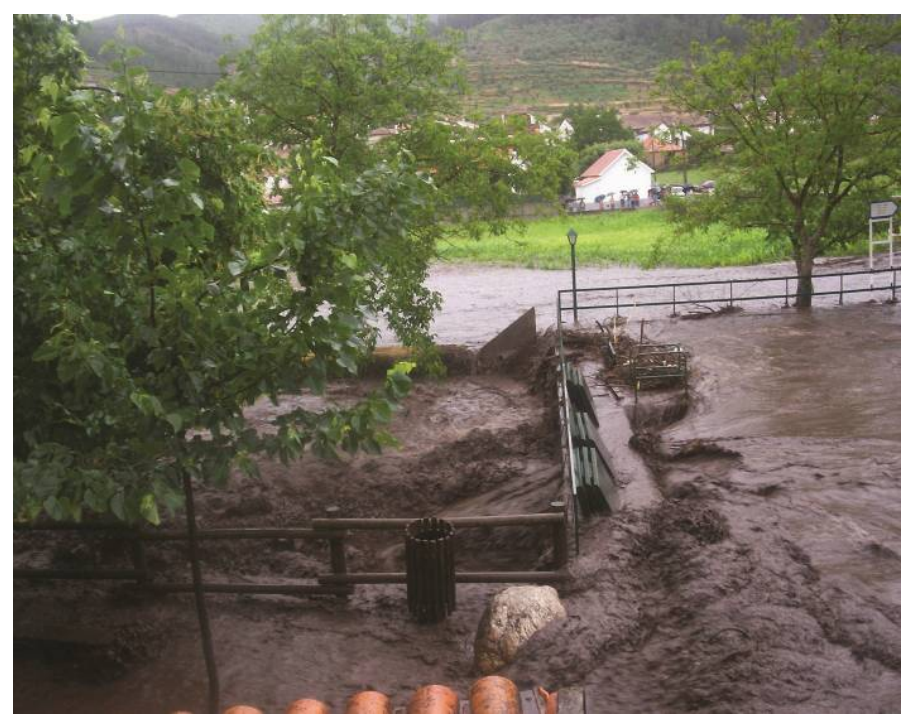

Figure 4. The super-elevation of the flow at Pomares Bridge and the flooding of the right bank of the river.

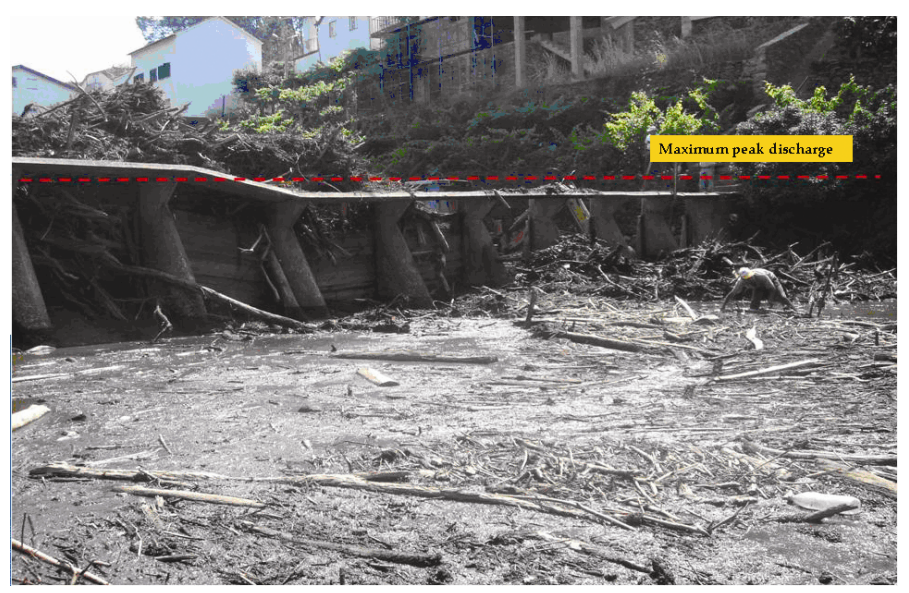

Figure 5. Simulation of maximum peak discharge and the blocked organic and sediment debris (Pomares Bridge).

Upstream, at the of Sobral Magro and Soito da Ruiva river beaches the flood marks were also evident, as can be seen in figures and 6,7 and 8. At Soito da Ruiva, the stream overflowed on both banks (Figure 6). In the Piodão basin the hydrological effects were also visi- 
ble, particularly affecting the Piodão, Foz da Égua and Vide river beaches, where flash floods were recorded (Figure 3).

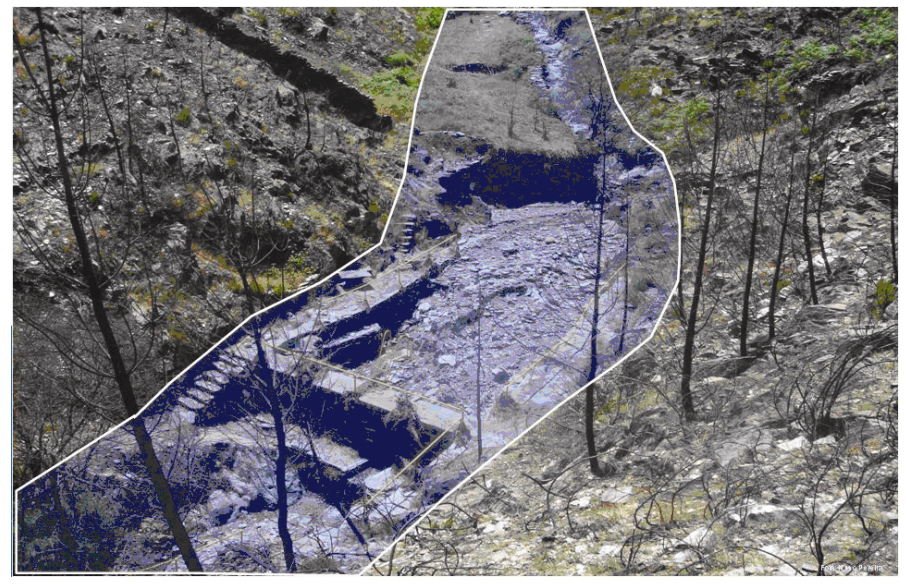

Figure 6. Simulation of the peak bank flood at Soita da Ruiva in the Pomares basin.

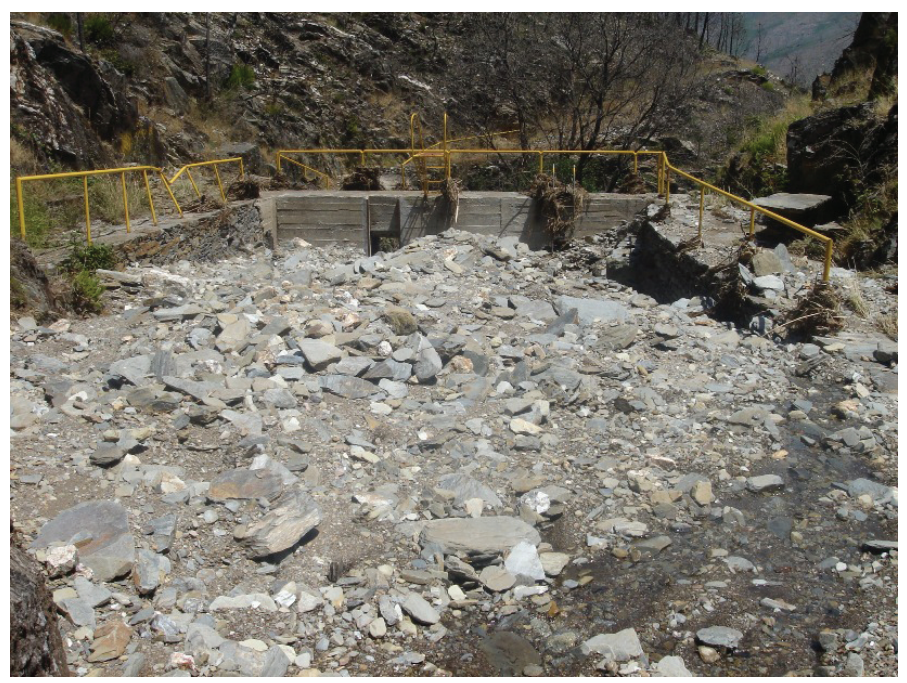

Figure 7. Deposition of sediment at Soito da Ruiva, in the Pomares basin.

During reconnaissance of the watersheds, widespread geomorphological consequences of the event were identified. In fact, high volume discharges have great erosional energy and the natural and man-made structures (dykes and bridges) along the rivers created obstacles to the transport of sediment and led to deposition throughout the main river channel and 
tributaries. However, the volume of off-site eroded sediment after a wildfire is difficult to assess because its response to rainstorms and runoff has different characteristics. The debris that was transported was mainly sediment from the thalwegs of tributaries that had been loosened by daily weathering and erosion, but could only be moved by large events.

Figures 7 and 8 show a plan of the debris flow deposition area caused by the inability of the drainage ditches to cope with the increased run-off generated in the upstream areas and the soil erosion, which led to flooding and the accumulation of large boulders and woody debris.

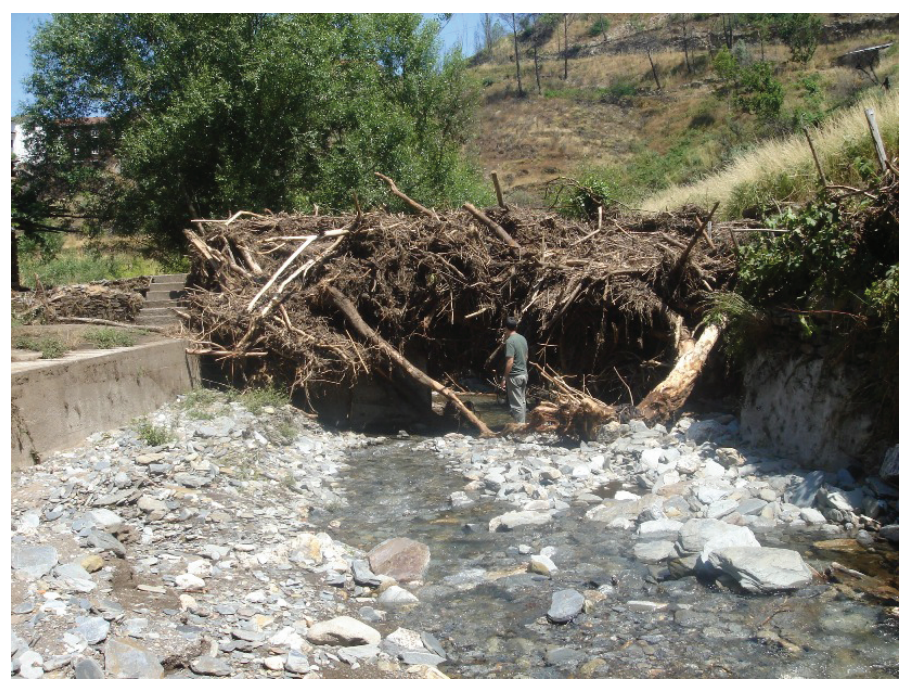

Figure 8. Wood accumulation following the wildfire at Sobral Magro, in the Pomares basin.

\subsection{The event of $14^{\text {th }}$ July 2006}

In July, the precipitation was higher than the precipitation recorded in June, totalling $95 \mathrm{~mm}$ (Figure 9). This second event also registered very intensive rainfall. In fact, about 70mm fell in two days, on $13^{\text {th }}$ and $14^{\text {th }}$ July, registering $30 \mathrm{~mm}$ and $39 \mathrm{~mm}$, respectively. The rainfall recorded on $14^{\text {th }}$ July was concentrated in one single event that occurred between $4 \mathrm{pm}$ and $5 \mathrm{pm}$. The total precipitation in the first half hour was $14 \mathrm{~mm}$, followed by $24 \mathrm{~mm}$ in the next 30 minutes.

According to the Portuguese Meteorological Services, the heavy rainfall in several areas of inland Portugal was associated with "high atmospheric instability" related to the formation of a thermal low in the interior of the Iberian Peninsula, typical of the summer months. The summer heat in the Iberian Peninsula causes the surface pressure low (Alonso et al., 1994). If the Iberian thermal low draws air from the Atlantic rather than Africa, incursive winds can become humid, conditions become unstable, and intense thunderstorms may occur (Linés, 1977), sometimes leading to torrential rain. 
According to Jarrett (2001), convective thunderstorms are known to have sharp rainfall gradients and rainfall intensities and vary in size, so that entire watersheds are not necessarily subjected to the same rainfall intensity.

The natural consequence of these precipitation patterns, which are relatively common in this climate, is that neighbouring watersheds receive different amounts of rainfall and therefore respond differently to the event. In fact, this event was more localised in comparison with the event of $16^{\text {th }}$ June, mainly affecting the headwaters of the Piodão stream. The heavy rainfall significantly increased the amount of streamflow, resulting in a stronger and faster response and generating downstream floods and serious damage due to sediment transport. In addition to the substantial damage to human infrastructures, one death was recorded.

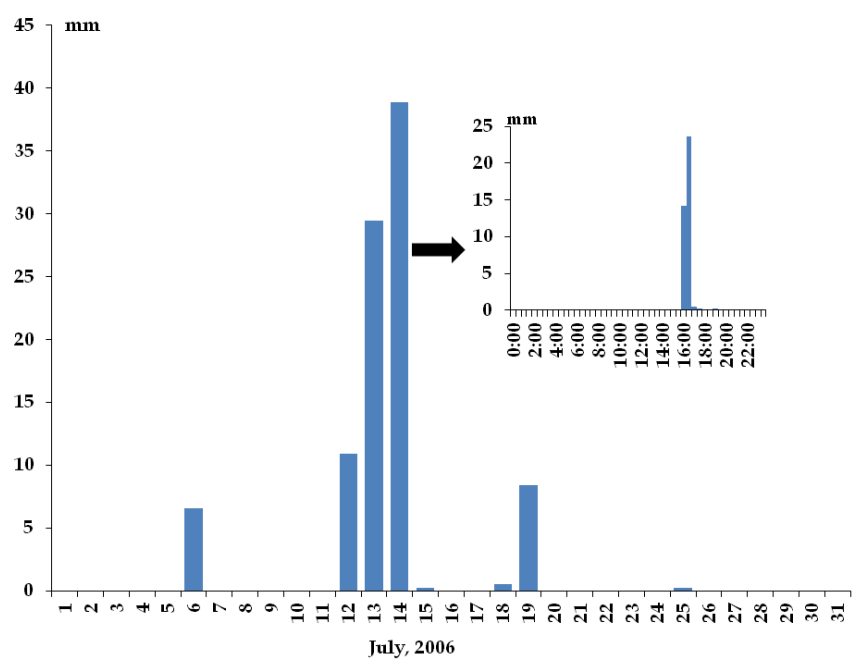

Figure 9. Daily distribution of rainfall in July and bi-hourly distribution on $14^{\text {th }}$ July.

Figure 10, provided by a local resident and showing the volume of accumulated water, demonstrate that the peak discharge was higher during this event than the previous one. The flood marks on the house used to estimate the peak discharge level show that the ground floor was not flooded in the $16^{\text {th }}$ June event, whereas during this flash flood the building was flooded to a depth of 1 metre.

The diagram in Figure 11 shows the longitudinal profile and different cross-sections of the Piodão river upstream of the village of Piodão, defines the stream bed and simulates the flood bed on the basis of flood marks, for the event of $14^{\text {th }}$ July. Overall, the stream overflowed its banks and doubled in size in comparison to the "normal" bed. Immediately upstream of the village of Piodão, the flooded area was triple the size of the stream bed. This expansion of the flooded area was associated with a man-made structure designed as a channel for the bed stream. The inability to drain off the flow of water led to an increase in 
the flooded area, with profound geomorphologic consequences. The force of the water demolished a bridge which a tourist was crossing at the time, leading to his death. A car park was partially destroyed by the water, causing a landslide, as can be seen in figure 12 .
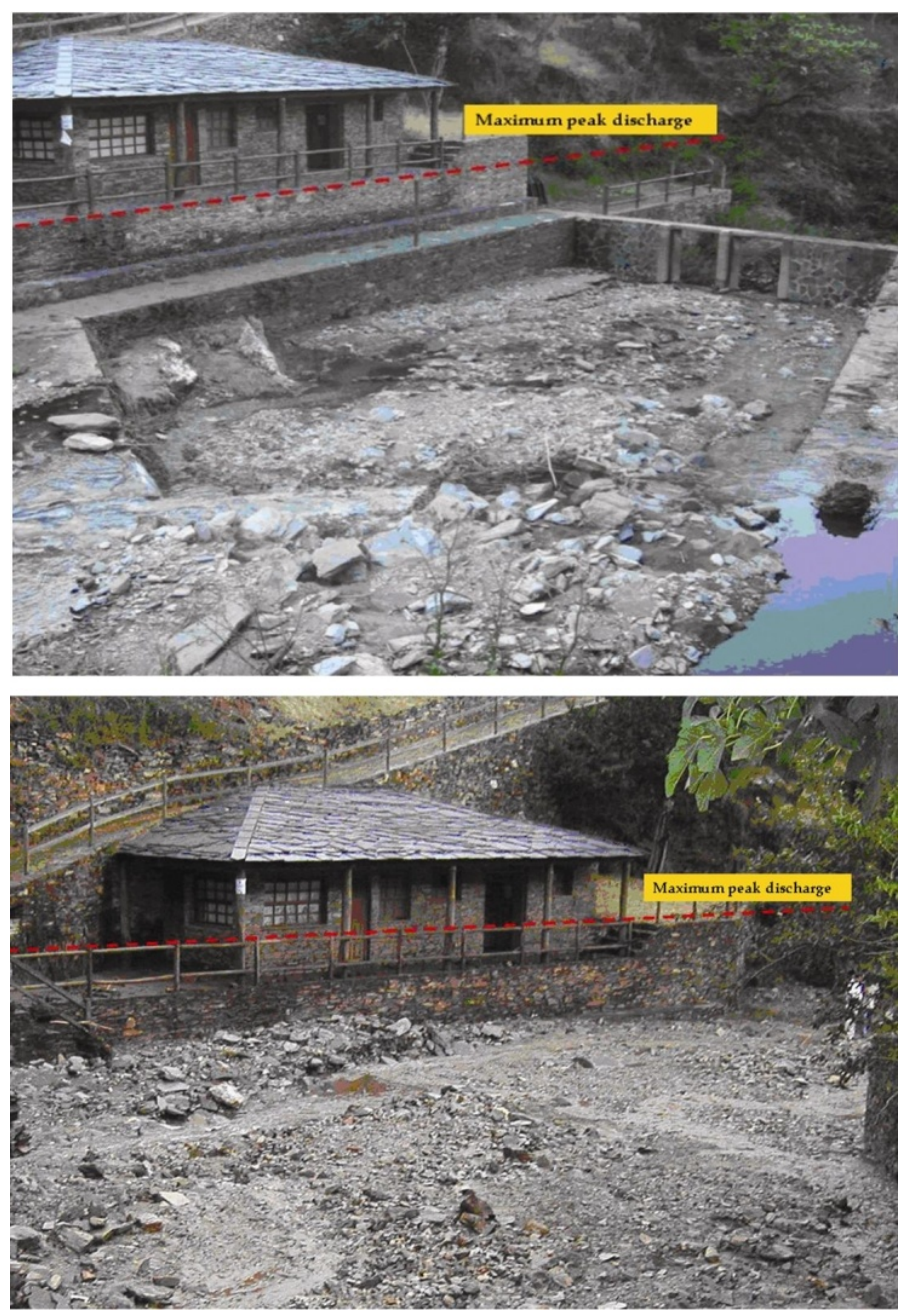

Figure 10. Simulation of the maximum peak discharge in the $16^{\text {th }}$ june (above) and in the $14^{\text {th }}$ July (below). Comparative analysis.

In fact, intense rainfall increases the erosive power of overland flow, resulting in deeply incised channels, such as rills and gullies (figure 13), and accelerates the removal of material from hill slopes. Increased runoff can also erode significant volumes of material from channels. The net result of rainfall on burned basins is the transport and deposition of large volumes of sediment, both within and downstream of the burned areas. The following 
photographs illustrate its powerful capacity to transport materials along the main channel and its highly destructive force (Figures 14 and 15). In figure 14 a large block can be observed abandoned in the river bed. In figure 15 a trout pond is crammed with material transported by the flood. The power of the stream affected sediment transport processes during the flood, also influencing the morphology of the river.

\section{Discussion}

Wildfire is an important, and sometimes the most important, driving force behind landscape degradation in the Mediterranean region (e.g. Naveh, 1975; Andreu et al., 2001; Dimitrakopoulos and Seilopoulos, 2002; Alloza and Vallejo, 2006; Mayor et al., 2007). In fact, wildfire can have profound effects on a watershed. Burned catchments are at increased hydrological risk and respond faster to rainfall than unburned catchments (Meyer et al. 1995; Cannon et al. 1998; Ferreira et al. 2008; Stoof, 2012). Therefore, flooding and soil erosion also represent some of the most significant off-site impacts of wildfires, causing serious damage to public infrastructures and private property, as well as increased psychological stress for the affected population.

Wildfire alters the hydrological response of watersheds, including the peak discharge resulting from subsequent rainfall.

Peak discharge is also directly related to flood damage, and it is therefore important to understand the relationship between rainfall and peak discharge. The analysis of rainfall-runoff relations suggests that in the case of burned watersheds a rainfall intensity threshold exists, implying a critical change in the behaviour of the hydrological response. This threshold has been estimated at around $10 \mathrm{~mm} \mathrm{~h}^{-1}$ (Krammes \& Rice, 1963; Doehring, 1968; Mackay and Cornish, 1982; Moody and Martin, 2001). One of the main reasons for the existence of a critical threshold intensity could be the hill slope infiltration rate. Infiltration rates have been shown to decrease by a factor of two to seven after wildfires (Cerdà, 1998; Martin \& Moody, 2001), meaning that post-fire rainfall intensities that exceed this infiltration rate and cause runoff may be lower than the pre-fire intensities required to produce a comparable runoff. Below approximately $10 \mathrm{~mm} \mathrm{~h}^{-1}$ the rainfall intensity may be below the average watershed infiltration rate, meaning that most of the rainfall infiltrates, with some transient runoff (Ronan, 1986) and some subsurface flow, which may either cause quickflow (Hewlett and Hibbert, 1967) in the channel or a lagged response. Above $10 \mathrm{~mm} \mathrm{~h}^{-1}$ the rainfall intensity may exceed the average watershed infiltration rate, so that the runoff is dominated by sheet flow, which produces flash floods. As an example, Martin and Moody (2001), consider if the rainfall intensity is $20 \mathrm{~mm} \mathrm{~h}^{-1}$, the unit-area peak discharge response would be 27 times greater than the response if the rainfall-runoff relation had not exceeded the $10 \mathrm{~mm} \mathrm{~h}^{-1}$ threshold. The same authors consider that if the rainfall intensity is $55 \mathrm{~mm} \mathrm{~h}^{-1}$ the response will be 700 times greater.

The consumption of the rainfall-intercepting canopy and soil-mantling litter and duff, intensive drying up of the soil, combustion of soil-binding organic matter, and enhancement or formation of water-repellent soils are factors that reduce rainfall infiltration into the soil and 
significantly increase overland flow and runoff in channels. The removal of obstructions to flow, such as live and downed timber and plant stems, due to wildfire can increase the erosive power of the overland flow, accelerating the removal of material from hill slopes. Increased runoff can also erode significant amounts of material from channels. The net result of rainfall on burned basins is often the transport and deposition of large volumes of sediment, both within and downstream of the burned areas (Cannon et al., 2008; Cannon 2005).

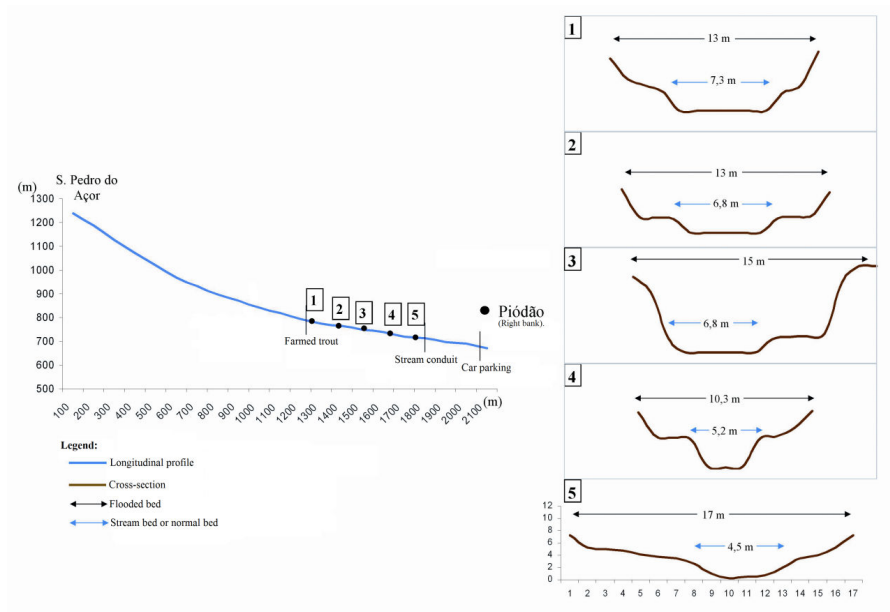

Figure 11. Profile and different cross-sections of the Piodão river upstream of the village of Piodão and normal and flooded area in the event of $14^{\text {th }}$ July.

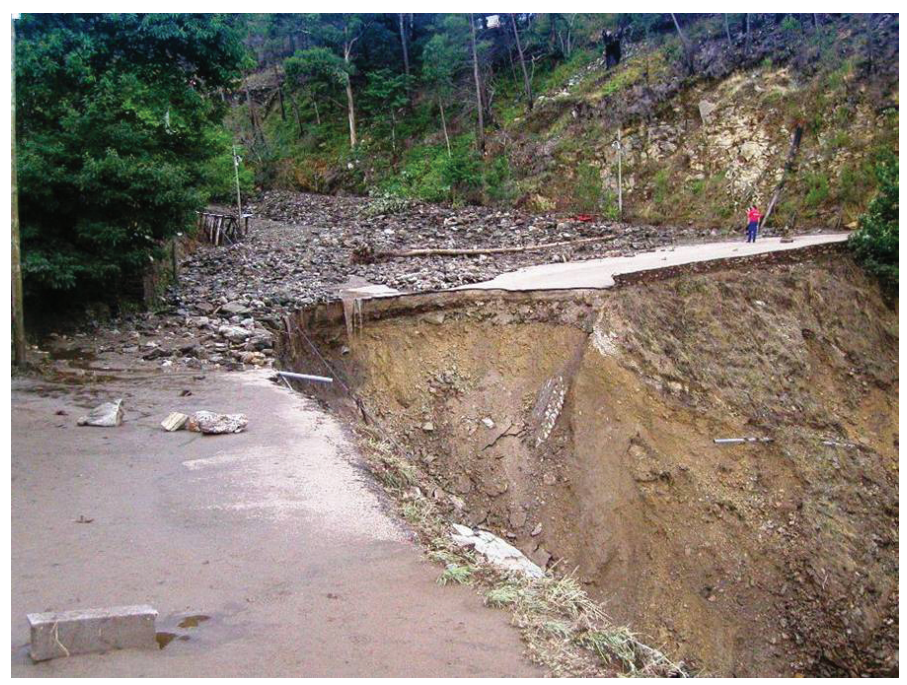

Figure 12. A car park partially destroyed by the water, causing a landslide. 


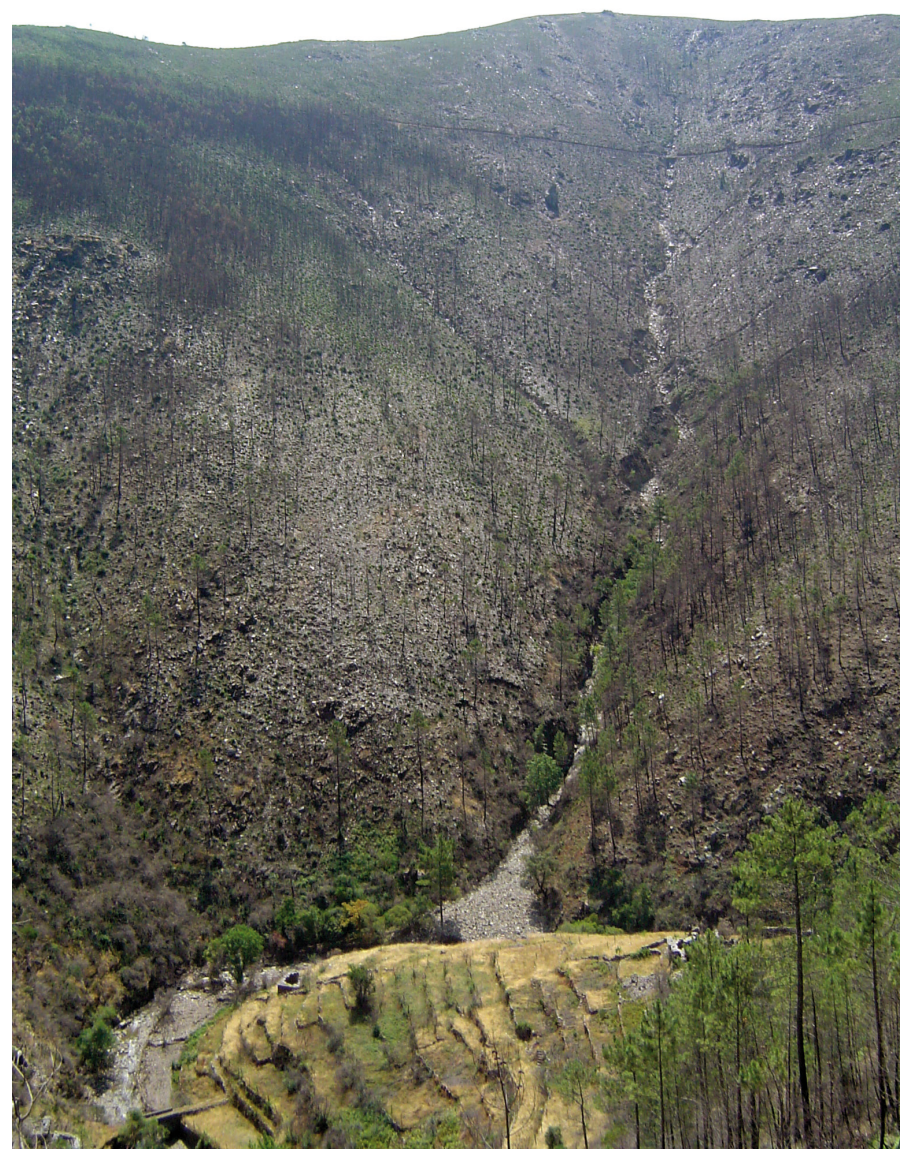

Figure 13. Rills and gullies erosion as a consequence of the intense rainfall.

Post-fire debris flows are generally triggered by one of two processes: surface erosion caused by rainfall runoff, and landslides caused by the infiltration of rainfall into the ground. Runoffdominated processes are by far the most common, since fires usually reduce the infiltration capacity of soils, which increases runoff and erosion. Infiltration processes are much less common, but prolonged heavy rain may increase soil moisture even after a wildfire. The wet soil may then collapse, producing infiltration-triggered landslides (Johnson, 2005).

According to (Johnson, 2005), although debris flows can occur in areas lying on almost any rock type, the areas most likely to produce debris flows are those lying on sedimentary or metamorphic rocks with more than around $65 \%$ of the area moderately or severely burned. In addition, debris flows are most frequently produced from steep $(>20)$, tightly confined drainage basins with an abundance of accumulated material, and are unlikely to extend be- 
yond the mouths of basins larger than about 25 square kilometres (Johnson, 2005). The numerous instances of debris flows found in the study area suggest that the bedrock must have been highly fractured and weathered in order to be transported by the flow.

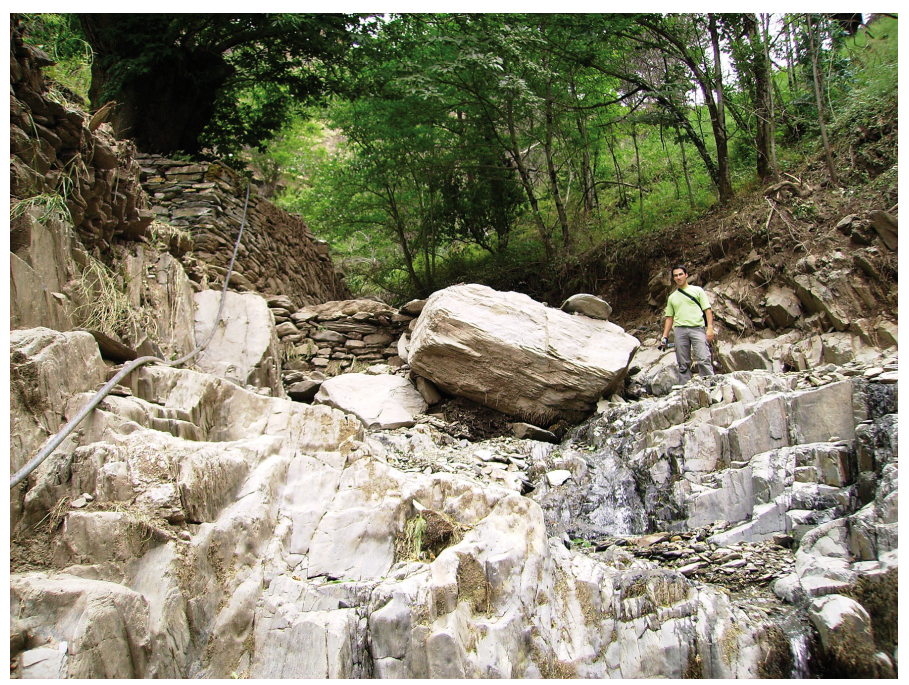

Figure 14. The powerful capacity to transport materials along the main channel during the event of $14^{\text {th }}$ July.

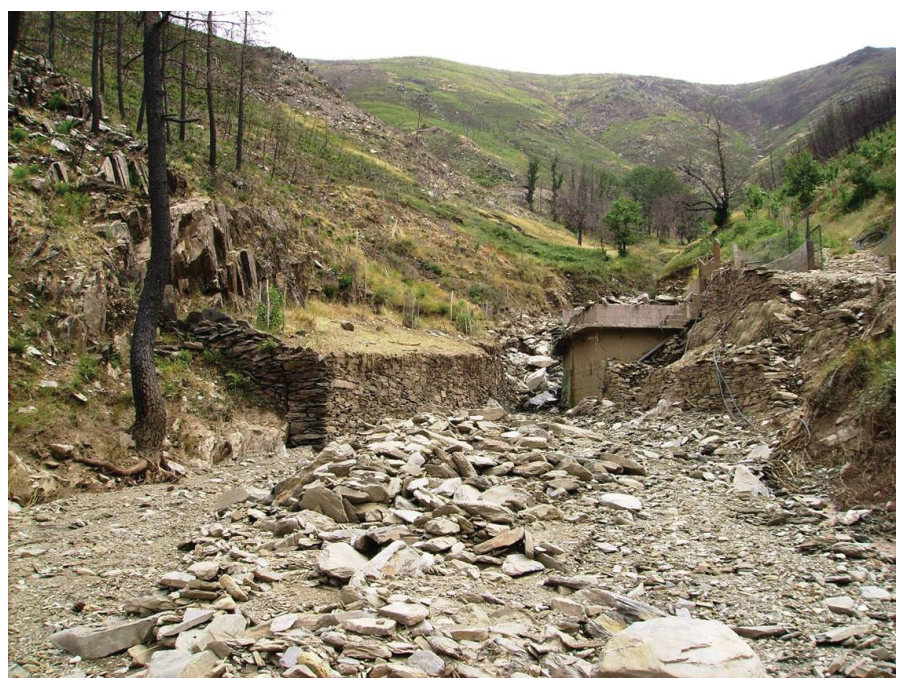

Figure 15. A trout pond is crammed with material transported by the flood. 
Despite the fact that the events studied occurred one year after the wildfires, it would be expected that the stream flow and erosion response would be much lower after vegetation regrowth and the removal of some of the sediment by relatively smaller storms in the following autumn and winter. Nevertheless, post-fire threshold conditions change over time even though the sediment supplies are depleted and the vegetation recovers, and the net result of intense rainfall on these burned basins was flash flooding in several areas and the transport and deposition of large volumes of sediment, both within and downstream of the burned areas. DeBano (2000) and Loaiciga (2001) consider that wildfires increase the magnitude of runoff and erosion and alter the hydrological response of watersheds resulting from subsequent rainfall, creating a risk for downstream communities that lasts for 1-3 years after a fire. Several other authors (Rowe et al., 1954; Doehring, 1968; Scott and Williams, 1978; Wells et al., 1979; Helvey, 1980; Robichaud et al., 2000) extend the "window of disturbance" to a much longer period of 3-10 years.

\section{Conclusion}

The hydrogeomorphic consequences of the 2006 events were identified during the field survey and it was found that there were widespread effects in the valleys of the watershed as well as in the main river channel and tributaries. In the Piodão and Pomares river basins, there were many instances of bed lowering, channel widening, avulsion and deposition. In several valleys there were flood marks, shallow landslides, slope failures and erosion gullies due to the intense rainstorm registered in both events. There were several instances of damage to infrastructures and buildings and one human life was lost.

Fires, floods and intensive erosion are a regular part of the landscape in mountainous regions around the world (Tryhorn et al., 2007) and are particularly significant in the Mediterranean basin, where forest fires have been increasing (JRC, 2005) and the climate is characterised by intense rainfall as a consequence of strong cyclogenesis (Kostopoulou, 2003). However, this intense rainfall has also been associated with factors other than cyclogenesis. Estrela et al. (2000) show that orographically induced thunderstorms caused by the Iberian thermal low can produce large volumes of precipitation. Post-fire floods may be associated with several different meteorological mechanisms and may either occur immediately after the fire or be delayed by several weeks or even years. Delayed floods are more likely to be caused by surface modifications that reduce infiltration, with precipitation due either to a large-scale drought break or localised thunderstorms. In combination, these processes can create a greater potential for severe flooding and intense erosive processes. A single intense rainstorm can generate peak flows which produce $75 \%$ of the sediment eroded during a longer (7-year) period of study (Shakesby, 2011).

In Portugal, several mountain areas have been affected by flash floods and landslides after forest fires. As an example, about 2 decades previously a major fire, which occurred in September 1987 and burnt an area of 10900 ha, affected most of the Pomares and Piodão basin area (Lourenço, $1988 ; 2006 \mathrm{a}$ b). A storm with similar characteristics to those in this study oc- 
curred in 2006, generating flash floods and severe erosion. Lourenço (1994) also studied a landslide which occurred in the Serra da Estrela mountains (in granitic lithology), after a severe rainfall event in October 1993, in an area burnt in August 1991. In the northern region of Portugal, Pedrosa et al. (2001) also studied a landslide that destroyed the great part of village of Frades (Arcos de Valdevez). This landslide also occurred in a granitic soil and was linked with a fire that occurred a few months before and destroyed the plant cover.

There is therefore a need to develop tools and methods to identify and quantify the potential hazards posed by flash floods and landslides generated by burned watersheds. An analysis of data collected from studies of flash flooding and debris flows following wildfires can answer many of the questions that are fundamental to post-fire hazard assessment-what and why, where, when, how big, and how often?

In fact, it is necessary to improve predictions of the magnitude and recurrence of the flooding that follows wildfires, due to the increased human population at risk in the wildlandurban interface. By understanding the magnitude of the runoff response and the erosion and deposition responses of recent wildfires, we can minimise loss of life and damage to property and provide data for landscape evolution in areas prone to wildfire. Moreover, watershed-scale predictions of erosion and deposition caused by these natural disasters can be used by land managers to prioritise forestry measures based on the erosion potential before and after wildfires.

\section{Author details}

L. Lourenço, A. N. Nunes ${ }^{1}$, A. Bento-Gonçalves ${ }^{2}$ and A. Vieira ${ }^{2}$

*Address all correspondence to: adelia.nunes@ci.uc.pt

1 Centro de Estudos em Geografia e Ordenamento do Território (CEGOT), Departamento de Geografia da Faculdade de Letras, Universidade de Coimbra, Portugal

2 Centro de Estudos em Geografia e Ordenamento do Território (CEGOT), Departamento de Geografia, Universidade do Minho, Campus de Azurém, Portugal

\section{References}

[1] Alloza, J. A., \& Vallejo, V. R. (2006). Restoration of burned areas in forest management plans. In: Desertification in the Mediterranean Region: a Security Issue, W.G. Kepner, J.L. Rubio, D.A. Mouat \& F. Pedrazzini (eds), 475-488, 1402037597, Springer, Dordrecht.

[2] Alonso, S., Portela, A., \& Ramis, C. (1994). First considerations on the structure and development of the Iberian thermal low-pressure system. Ann. Geophys., 12, 457-468, 0992-7689. 
[3] Andreu, V., Imeson, A. C., \& Rubio, J. L. (2001). Temporal changes in soil aggregates and water erosion after a wildfire in a Mediterranean pine forest. Catena, 44, 69-84, 0341-8162.

[4] Brown, J. A. H. (1972). Hydrologic effects of a bushfire in a catchment in south-eastern New South Wales. Journal of Hydrology, 15, 77-96, 0022-1694.

[5] Cannon, S., Powers, P., \& Savage, W. (1998). Fire-related hyperconcentrated and debris flows on Storm King Mountain, Glenwood Springs, Colorado, USA. Environ. Geol., 35, 210-218, 0943-0105.

[6] Cannon, S. H., \& Gartner, J. E. (2005). Wildfire-related debris flow from a hazards perspective. In: Debris-flow hazards and related phenomena, O. Hungr \& M. Jacob (eds.), 321-344, 978-3540207269, Springer, Praxis Books in Geophysical Sciences.

[7] Cannon, S. H. (2000, 16-18 August). Debris-flow response of southern California watersheds recently burned by wildfire. Paper presented at Proceedings of the Second International Conference on Debris-Flow Hazards Mitigation, Taipei, Taiwan. In: Debris-Flow Hazards Mitigation- Mechanics, prediction, and assessment, G.F. Wieczorek $\mathcal{E}$ N.D. Naeser (eds.), 45-52, 905809149X, Rotterdam.

[8] Cannon, S. H. (2001). Debris-flow generation from recently burned watersheds. Environmental and Engineering Geoscience, 7, 321-341, 1078-7275.

[9] Cannon, S. H. (2005). Southern California-Wildfires and debris flows. U.S. Geological Survey Fact Sheet, 2005-3106, http//pubs.usgs.gov/fs/2005/3106.

[10] Cannon, S. H., Gartner, J. E., Wilson, R. C., \& Laber, J. L. (2008). Storm rainfall conditions for floods and debris flows from recently burned areas in southwestern Colorado and southern California. Geomorphology, 96, 250-269, 0169-555X.

[11] Cannon, S. H., Kirkham, R. M., \& Parise, M. (2001). Wildfire-related debris-flow initiation processes, Storm King Mountain, Colorado. Geomorphology, 39, 171-188, 0169-555X.

[12] Carvalho, T. M., Coelho, C. O. A., Ferreira, A. J. D., \& Charlton, C. A. (2002). Land degradation processes in Portugal: Farmers' perceptions of the application of European agroforestry programmes. Land Degradation $\mathcal{E}$ Development, 13, 177-188, 1099-145X.

[13] Cerdà, A. (1998). Post-fire dynamics of erosional processes under Mediterranean climatic conditions. Zeitschrift fuer Geomorphologie Neue Folge, 42(3), 373-398, 0375-8109.

[14] Coelho, C. O. A., Ferreira, A. J. D., Boulet, A. K., \& Keizer, J. J. (2004). Overland flow generation processes, erosion yields and solute loss following different intensity fires. Quarterly Journal of Engineering Geology and Hydrogeology, 37, 233-240, 1470-9236.

[15] Conedera, M., Marxer, P., Ambrosetti, P., Bruna, G. D., \& Spinedi, F. (1998). The 1997 forest fire season in Switzerland. Int. For. Fire News, 18, 85-88, 1029-0864. 
[16] DeBano, L. F., Neary, D. G., \& Ffolliott, P. F. (1998). Fire's Effects on Ecosystems, 0-47116-356-2, Wiley \& Sons, New York.

[17] DeBano, L. F. (2009, March/April). Fire Effects on Watersheds: an overview. Southwest Hydrology, 2, 1552-8383.

[18] Dimitrakopoulos, A. P., \& Seilopoulos, D. (2002). Effects of rainfall and burning intensity on early post-fire soil erosion in a Mediterranean forest of Greece. In: Proceedings of the Third International Congress. Man and Soil at the Third Millennium, J.L. Rubio, R.P.C Morgan, S. Asins \& V. Andreu (Eds.), II, 1351-1357, 84-87779-45-X, Geoforma Ediciones, Logroño.

[19] Doehring, D. O. (1968). The effect of fire on geomorphic processes in the San Gabriel Mountains, California. In: Contributions to Geology, R.B. Parker (Ed.), 43-65, Laramie, University of Wyoming, Wyoming.

[20] Durão, R. M., Pereira, M. J., Costa, A. C., Delgado, J., Del Barrio, G., \& Soares, A. (2010). Spatial-temporal dynamics of precipitation extremes in southern Portugal: a geostatistical assessment study. International Journal of Climatology, 30(10), 1526-1537, 1097-0088.

[21] Linés, A. (1970). The climates of the Iberian Peninsula. In: Climates of Northern and Western Europe. C. C. Wallén (Ed.), 0042-9767, World Meteorological Organization.

[22] Ferreira, A. J. D., Coelho, C. O. A., Ritsema, C. J., Boulet, A. K., \& Keizer, J. J. (2008). Soil and water degradation processes in burned areas: lessons learned from a nested approach, Catena, 74, 273-285, 0341-8162.

[23] Ferreira, A. J. D., Coelho, C. O. A., Shakesby, R. A., \& Walsh, R. P. D. (1997). Sediment and solute yield in forest ecosystems affected by fire and rip-ploughing techniques, central Portugal: a plot and catchment analysis approach. Physics and Chemistry of the Earth, 22, 309-314, 1474-7065.

[24] Helvey, J. D. (1980). Effects of a north central Washington wildfire on runoff and sediment production. Water Resources Bulletin, 16(4), 627-634, 0043-1370.

[25] Hewlett, J. D., \& Hibbert, A. R. (1967). Factors affecting the response of small watersheds to precipitation in humid areas. In: Forest Hydrology, Proceedings of a National Science Foundation Advance Science Seminar, WE Sopper \& HW Lull (eds), 275-290, Pergamon Press, New York.

[26] Hershfield, D. M. (1961). Rainfall frequency atlas of the United States for duration from 30 minutes to 24 hours and return periods from 1 to 100 years. US Department of Commerce, Technical Paper [40], 0-938909-67.

[27] Jarrett, R. D. (1987). Errors in slope-area computations of peak discharges in mountain streams. Journal of Hydrology, 96, 53-67, 0022-1694.

[28] JRC. (2005). Forest fires in Europe 2004. Joint Research Center S.P.1.05.147 EN 978-9-27916-494-1 European Communities 
[29] Johnson, M. L. (2005). Southern California-Wildfires and Debris Flows. U.S. Department of the Interior, U.S. Geological Survey, 4, 0196-1497.

[30] Kostopoulou, E. (2003). The relationships between atmospheric circulation patterns and surface climatic elements in the eastern Mediterranean. University of East Anglia, Ph.D. thesis, 407.

[31] Krammes, J. S., \& Rice, R. M. (1963). Effect of fire on the San Dimas experimental forest. In: Arizona Watershed Symposium, Proceedings 7th Annual Meeting, 0471 74283 X Phoenix, Arizona , 31-34.

[32] Langford, K. J. (1976). Change in yield of water following a bushfire in a forest of eucalyptus regnans. Journal of Hydrology, 29(1-2), 87-114, 0022-1694.

[33] Lavabre, J., Torres, D. S., \& Cernesson, F. (1993). Changes in the hydrological response of a small Mediteranean basin a year after a wildfire. Journal of Hydrology, 142, 273-299, 0022-1694.

[34] Letey, J. (2001). Causes and consequences of fire-induced soil water repellency. Hydrological Processes, 15, 2867-2875, 1099-1085.

[35] Loaiciga, H. A., Pedreros, D., \& Roberts, D. (2001). Wildfire-streamflow interaction in a chaparral watershed. Advances in Environmental Research, 5, 295-305, 1093-7927.

[36] Lourenço, L. (1988). Tipos de tempo correspondentes aos grandes incêndios florestais ocorridos em 1986 no Centro de Portugal. Finisterra, 23, Lisboa, 251-270, 0430-5027.

[37] Lourenço, L., Pedrosa, A., \& Felgueiras, J. (2001). Movimentos em massa. Exemplos ocorridos no Norte de Portugal, ENB. Revista Técnica e Formativa da Escola Nacional de Bombeiros, 17, Sintra, 25-39, 1645-0086.

[38] Lourenço, L. (1994, 15 a 17 de Dezembro). A Enxurrada do Ribeiro de Albagueira. III Congresso Florestal Nacional, Figueira da Foz, 1-9.

[39] Lourenço, L. (2006a). (Cood) Paisagens de Socalcos e Riscos Naturais em vales do Rio Alva, Colectâneas Cindínicas VI, Projecto Interreg III B/Sudoe-Terrisc, 9-72833-020-0 de Investigação Científica de Incêndios Florestais da Faculdade de Letras da Universidade de Coimbra, Lousã, 192 p.

[40] Lourenço, L. (2006b). (Cood). Bacias hidrográficas das ribeiras do Piódão e de Pomares (Concelho de Arganil). Terrisc- Recuperação de paisagens de socalcos e prevenção de riscos naturais nas serras do Açor e da Estrela, Relatório Técnico 0605, 9-72994-626-4 Interreg III B/Sudoe-Terrisc, Núcleo de Investigação Científica de Incêndios Florestais da Faculdade de Letras da Universidade de Coimbra, Lousã, Portugal

[41] Lourenço, L. (2007). (Cood). Riscos Ambientais e Formação de Professores (Actas das VI Jornadas Nacionais do Prosepe), Colectâneas Cindínicas VII, 9-72833-021-7 de Sensibilização e Educação Florestal e Núcleo de Investigação Científica de Incêndios Florestais e Faculdade de Letras da Universidade de Coimbra, Coimbra, Portugal 
[42] Lourenço, L. (1989). Quantificação da erosão produzida na serra da Lousã na sequência de incêndios florestais. Resultados preliminares. Relatório Técnico no816, 972-9038-66X GMF, Coimbra.

[43] Lourenço, L. (1996). Serras de Xisto do Centro de Portugal- Contribuição para o seu conhecimento geomorfológico e geo-ecológico. PhD, Universidade de Coimbra, Portugal.

[44] Llovet, J., Ruiz-Valera, M., Josa, R., \& Vallejo, V. R. (2009). Soil responses to fire in Mediterranean forest landscapes in relation to the previous stage of land abandonment. International Journal of Wildland Fire, 18, 222-232, 1049-8001.

[45] Mackay, S. M., \& Cornish, P. M. (1982). Effects of wildfire and logging on the hydrology of small catchments near Eden, N.S.W. In: The First National Symposium of Forest Hydrology, 111-117, 82(6), 0-85825-175-2, Eng. Aust. Natl. Conf. Publ.

[46] Mayor, A. G., Bautista, S., Llovet, J., \& Bellot, J. (2007). Post-fire hydrological and erosional responses of a Mediterranean landscape: seven years of catchment-scale dynamics. Catena, 71, 68-75, 0341-8162.

[47] Meixner, T., \& Wohlgemuth, P. M. (2003, October 28-30). Climate variability, fire, vegetation recovery, and watershed hydrology. Benson, Arizona. In: Proceedings of the First Interagency Conference on Research in the Watersheds, 651-656, 978-1-40206-588-0.

[48] Meyer, G. A., Wells, S. G., \& Jull, A. J. T. (1995). Fire and alluvial chronology in Yellowstone National Park: Climatic and intrinsic controls on Holocene geomorphic processes. Geol. Soc. Amer. Bull., 107, 1211-1230, 1943-2674.

[49] Miller, J. F., Frederick, R. H., \& Tracey, R. J. (1973). Precipitation frequency Atlas of the Western United States, Colorado. NOAA Atlas 2, III, Nat. Weather Ser., Washington, DC, 0093-7177.

[50] Moody, J. A., \& Martin, D. A. (2001). Initial hydrologic and geomorphic response following a wildfire in the Colorado Front Range. Earth Surface Processes and Landforms, 26, 1049-1070, 1096-9837.

[51] Moody, J., Martin, D., \& Cannon, S. (2008). Post-wildfire erosion response in two geologic terrains in the western USA. Geomorphology, 95, 103-118, 0169-555X.

[52] Moreira, F., Viedma, O., Arianoutsou, M., Curt, T., Koutsias, N., Rigolot, E., et al. (2011). Landscape e wildfire interactions in southern Europe: implications for landscape management. Journal of Environmental Management, 92, 2389-2402, 0301-4797.

[53] Nasseri, I. (1989). Frequency of floods from a burned chaparral watershed. In: Berg, Neil H., tech. coord. Proceedings of the symposium on fire and watershed management; 1988 October 26-28; Sacramento, CA. Gen. Tech. Rep. PSW-109. Berkeley, CA: U.S. Department of Agriculture, Forest Service, Pacific Southwest Forest and Range Experiment Station: 68-71. Available from: National Technical Information Service, Springfield, VA 22161; PB89-228639. 
[54] Naveh, Z. (1975). The evolutionary sequence of fire in the Mediterranean region. Vegetatio, 29, 199-208, 0042-3106.

[55] Nunes, A. N. (2012). Regional variability and driving forces behind forest fires in Portugal an overview of the last three decades (1980-2009). Applied Geography, 34, 576-586, 0143-6228.

[56] Nunes, A. N. (2011). Soil erosion under different land use and cover types in a marginal area of Portugal. In Godone, D. E Stanchi, S. (eds.) Soil Erosion Studies, In Tech Open Access Publisher, 59-86, 978-9-53761-934-3, available in, http://www.intechweb.org/.

[57] Prosser, I. P., \& Williams, L. (1998). The effect of wildfire on runoff and erosion in native Eucalyptus forest. Hydrological Processes, 12, 251-265, 1099-1085.

[58] Rego, F. C. (1992). Land use changes and wildfires. In Responses of forest ecosystems to environmental changes A. Teller, P. Mathy, E J. N. R. Jeffers (Eds.), 367-373, 978-1851668786, Elsevier Applied Science, London.

[59] Robichaud, P. R., Mc Cool, D. K., Pannkuk, C. D., Brown, R. E., \& Mutch, P. W. (2001). Trap efficiency of silt fences used in hillslope erosion studies. In: Proceedings of the International Symposium, Soil Erosion Research for the $21^{\text {st }}$ Century, AscoughII II, J.C., Flanaga, D.C. (Eds.), American Society of Agricultural Engineers , 7-03-003239-X Q.420, St. Joseph, Michigan , 541-543.

[60] Robichaud, P. R., Beyers, J. L., \& Neary, D. G. (2000, September). Evaluating the effectiveness of postfire rehabilitation treatments. United States Department of Agriculture, Forest Service Rocky Mountain Research Station, General Technical Report RMRS-GTR-63, 89.

[61] Ronan, N. M. (1986). The hydrological effects of fuel reduction burning and wildfire at wallaby Creek. Melbourne and Metropolitan Board of Works, Report No. MMBWW-0015, 0-72416-738-2.

[62] Rowe, P. B., Countryman, C. M., \& Storey, H. C. (1954). Hydrologic analysis used to determine effects of fire on peak discharge and erosion rates in southern California, USDA Calif. Forest and range experiment station and University of California, Berkeley, CA, 49.

[63] Sala, M., Soler, M., \& Pradas, M. (1994). Temporal and spatial variations in runoff and erosion in burnt soils. Coimbra, Portugal. In: Proceedings of the Second International Conference on Forest Fire Research, 1123-1134, 972-97406-0-7, II.

[64] Scott, D. F., \& Van Wyk, D. B. (1990). The effects of wildfire on soil wettability and hydrological behaviour of an afforested catchment. Journal of Hydrology, 121, 239-256, 0022-1694.

[65] Scott, D. F. (1993). The hydrological effects of fire in South African mountain catchments. Journal of Hydrology, 150, 409-432, 0022-1694. 
[66] Scott, D. F. (1997). The contrasting effects of wildfire and clearfelling o the hydrology of a small catchment. Hydrological Processes, 11, 543-555, 1099-1085.

[67] Seibert, J., Mc Donnell, J. J., \& Woodsmith, R. D. (2010). Effects of wildfire on catchment runoff response: a modelling approach to detect changes in snow-dominated forested catchments. Hydrology Research, 41, 378-390, 0029-1277.

[68] Shakesby, R., \& Doerr, S. (2006). Wildfire as a hydrological and geomorphological agent. Earth-Science Reviews, 74, 269-307, 0012-8252.

[69] Shakesby, R. A., Boakes, D., Coelho, C. O. A., Gonçalves, A. J. B., \& Walsh, R. P. D. (1996). Limiting the soil degradation impacts of wildfire in Pine and Eucalyptus forest in Portugal. Applied Geography, 16, 337-355, 0143-6228.

[70] Shakesby, R. A. (2011). Post-wildfire soil erosion in the Mediterranean: Review and future research directions. Earth-Science Reviews, 105, 71-100, 0012-8252.

[71] Shakesby, R. A., \& Doerr, S. H. (2006). Wildfire as a hydrological and geomorphological agent. Earth Science Reviews, 74, 269-307, 0012-8252.

[72] Stoof, C. R., Vervoort, R. W., Iwema, J., Elsen, E., Ferreira, A. J. D., \& Ritsema, C. J. (2012). Hydrological response of a small catchment burned by experimental fire. $\mathrm{Hy}$ drol. Earth Syst. Sci., 16, 267-285, 1027-5606.

[73] Tryhorn, L., Lynch, A., \& Abramsom, A. (2007). On the Meteorological Mechanisms Driving Postfire Flash Floods: A Case Study. Monthly Weather Review, 136, 1778-1791, 0027-0644.

[74] Wells, W. G., II. (1981). Some effects of brushfires on erosion processes in coastal Southern California. In: Erosion and Sediment Transport in Pacific Rim Steeplands [132], 305-342, 0-94757-111-6, IAHS.

[75] Wilson, C. J. (1999). Effects of logging and fire on runoff and erosion on highly erodible granitic soils in Tasmania. Water Resources Research, 35(11), 3531-3546, 0043-1397. 